\title{
60 YEARS OF KARST RESEARCH INSTITUTE ZRC SAZU: THE INSIDER'S STORY OF WHO IS WHO AT THE KARST RESEARCH INSTITUTE
}

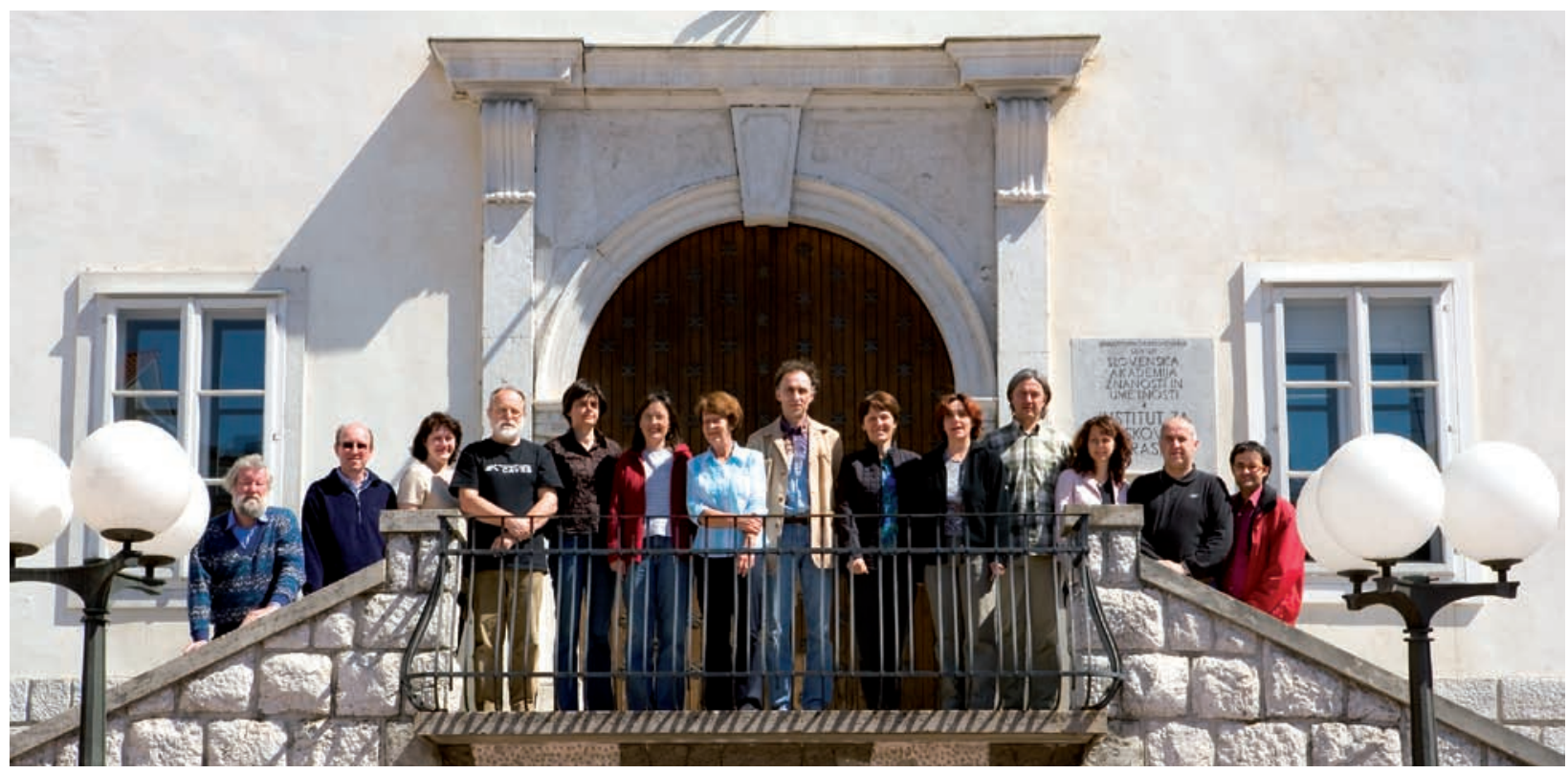

The institute behind this journal has recently celebrated its $60^{\text {th }}$ anniversary. Since 1947, when founded by the Slovene Academy of Sciences and Arts, the Institute has gone through many changes, the team has grown from few to more than twenty and is currently one of the largest institutes of Academy's Scientific Research Centre.

Karst research in most countries is distributed among different, mainly earth science, departments of universities, institutes and museums. There are few „old“ karst institutes in the world, not surprisingly in Slovenia, Romania and China, where karst has always posed many questions to the local population. Founding of new karst institutes around the globe (e.g. USA, Ukraine, Switzerland, Croatia, Germany...) shows that the idea of joining karst research under „one roof“ is not at all outmoded.

Instead of a general description of Institute's work, let me introduce the insider's story of the Karst Research Institute ZRC SAZU. There are 22 people working at the institute now. These are the people to whom this essay is dedicated.

We come from different backgrounds; we are geologists, geographers, chemist, biologist, microbiologist and physicist. Karst, as we know, is a very complex natural, cultural and social phenomenon. It is like a complex sculpture that needs different viewpoints to see the whole picture. That is why our diversity is good. As all of you working in interdisciplinary teams will agree, there is also a weakness in such a diversity; sometimes different views do not merge together.

Though it looks like that such team has been "intelligently designed" it is not so, nor it is just a coincidence. We could say that the team has continuously been subjected to the natural selection.

So Who is who at the institute, in a random order, starting with a head?

Tadej Slabe has been leading the Institute for more than a decade. As a geographer by training and top rock climber he has held to the fine structure of karst relief also in his professional life. He has devoted his research to rock relief on karst surface and underground. He uses field studies combined with physical models to study the formation of karst relief at different scales, from rillenkarren to the stone forests of South China karst.

Andrej Kranjc, a geographer, also the editor-inchief of AC has (co)-authored many regional karst studies. His particular interest have been fluvial sediments in karst. In his mature research period he has also focused to the history of karst science, which has a long and rich tradition in Slovenia. Andrej is the initiator and director of the first postgraduate program in karstology at the University of Nova Gorica. He is a member of the Slovene Academy of Sciences and Arts. 
For Andrej Mihevc, a geographer and a caver, the Institute was a logical choice. His research is very diverse, although we could name him a karst geomorphologist and speleologist. To understand a truly complex morphogenesis and related speleogenesis of Slovene karst regions, he uses different approaches, from DEM surface analyses to field and laboratory studies of sediments in karst. He is also responsible that unroofed caves have come to the list of the classical karst features. Andrej is one of the best known field trip guides in karst community (and the worst for those who want a dinner at 7 and bed at 9).

Nadja Zupan Hajna, a geologist, studied the relation between chemical and mechanical weathering in caves. But her interest in karst reaches is far broader. She studies cave minerals and particularly cave sediments. Together with Andrej Mihevc, Pavel Bosak and Peter Pruner she performed a broad palaeomagnetic study of cave sediments, which revealed a new timescale of morphogenesis and speleogenesis in some Slovene karst regions. Nadja is a current president of the Slovene Geological Society, which she takes as a duty rather than an honour.

Slovenia lies in tectonically very active area, where tectonics plays an important role in karst morphogenesis and speleogenesis. To demonstrate this, Stanka Šebela, a geologist, has done a detailed tectonic mapping in several large cave systems, including Postojnska jama, Škocjanske jame and Predjama. As a part of the COST programme, she studies active tectonic processes in caves. She uses high precision extensiometers to measure shifts in selected faults. Apart from the continuous movements, records show a larger shifts prior and during the major earthquakes, which is in correspondence with records from Eastern Italy and Czech republic.

As a chemist Janja Kogovšek is a natural choice for the leader of the Institute's hydrochemistry lab. Karst waters are her speciality. She has performed and analysed many tracing experiments in karst for applied and basic research. She studies flow and contaminant transport in the vadose zone of the karst aquifer. To this extent she has performed different tracing experiments in the vadose zone as well as continuous long-term study of chemical and physical parameters of different cave trickles.

Metka Petrič is a hydrogeologist studying the broad aspect of karst waters. Her doctoral research dealt with the linear system analysis of recharge-discharge relations in karst aquifers. Nowadays Metka uses different hydrological, hydrogeological and hydrochemical techniques to characterise karst aquifers in order to protect it and/or to study the basic principles of flow and transport in karst. She is involved in planning and performance of tracing experiments and studies of groundwater vulnerability.

Martin Knez, a geologist, focuses to the relation between lithology and karstification. He studied the role of bedding planes in the speleogenesis of Škocjan Caves. He is involved in the study and protection of features revealed during the motorway constructions in karst and future planning of new railway lines through the karst. Together with Tadej Slabe he has studied the role of lithology and structure in the formation of several stone forests in China.

Tanja Pipan, a biologist, studies life in karst underground. Slovene karst is a hot spot in underground biodiversity. Tanja's main research topic have been copepod communities in the epikarst. She has shown how epikarst presents an important habitat for the life on sub millimetre scale. Her research interest also includes the transport and abundance of nutrients in the karst in relation to the diversity of the cave biota. Tanja is also a Slovene co-ordinator of ILTER (International Long Term Ecological Research) network.

Janez Mulec is a microbiologist and therefore studies the life at its small scale. Many recent karstological studies have stressed the importance of micro-organisms in karst processes. Janez studies the occurrence of heterotrophic bacteria, algae and protozoa in cave environments and their role in active karst processes.

Bojan Otoničar, a geologist, studies paleokarst, a karst which developed during some karstification periods in the past. Re-submerged and covered with sediments such karst has become a part of a sedimentary record offering a wealth of information about the regional settings to a sedimentologist and karstologist. Bojan focused his research to the paleokarst of SW Slovenia, a part of the Adriatic $\neg$ carbonate platform which was exposed to karstification by meteoric waters due to emergence at the end of the Cretaceous and at the beginning of the Paleogene period.

Nataša Ravbar, a geographer, has recently become the first doctor in Karstology. Her doctoral thesis deals with one of the most important practical issues in karst: karst groundwater vulnerability and protection. Nataša proposed a novel Slovene approach towards mapping the vulnerability of karst aquifers. She successfully applied it to a regional catchment in Slovenia.

One of the institute's mission is also to bring up new karstologists. Two of them are currently heading towards their PhD in Karstology. Geographer Mitja Prelovšek is performing a wide range study of corrosion rates in epiphreatic zone of karst. To this extent he has installed more than 200 limestone tablets in 68 locations. He is combining the weight loss method with hydrochemical studies in order to see what is really going 
on in the cave rivers. Geologist Janez Turk is also focusing to the active cave flow, i.e. the epriphreatic zone. He studies the hydraulic of underground channels. For this he has installed a series of level-temperature loggers into selected caves with active flow, to obtain a dense time series which he analyses and interprets with different classical and novel methods.

The author of this essay is a physicist and a caver. His main research fields emerged from his doctoral studies with Wolfgang Dreybrodt in Bremen. He is involved in computer modelling of early speleogenesis. He has developed several computer models based on basic physical and chemical principles, to simulate the growth of initial channels in karst aquifers in different settings. He also studies nature and dynamics of other karst processes like condensation in caves, hydraulics of large conduits, rillenkaren development etc. Although his caving career is in (hopefully temporary) decline, he still keeps interest in alpine karst.

The research would not be possible without the support of the rest of the team: a secretary Sonja Stamenković, who keeps all formal things running, Maja Kranjc, who is maintaining one of the world's best karstological libraries, Mateja Zadel, who takes care for the chemical analyses, Jure Hajna, Leon Drame and Franjo Drole, who are giving the technical support to research teams and Slavica Sušak, who keeps the building tidy.

Institute's co-workers are aware of responsibility of being a part of a central karstological institution. Therefore, we often "forget" our particular research interests and join our forces in organising International Karstological School (16 so far), performing applied studies in groundwater and nature protection in karst, advising the management of show caves, managing the Slovene Cave cadastre together with the Slovene Speleological Association, teaching students at different Universities about karst, tuning the postgraduate school in karstology at the University of Nova Gorica etc.

In 60 years the Institute has become one of the centres of karst research, establishing close collaborations with many outstanding researchers around the world. Some of these have had so tight collaborations with the Institute that we consider them (also formally) as adjoined co-workers. These are Trevor Shaw and David J. Lowe from England, Pavel Bosak from Czech Republic and Wolfgang Dreybrodt from Germany.

Franci Gabrovšek Co-Editor 